\title{
NA CESTE DO CÁCH. UHORSKÝ PÚTNICKÝ KRÍŽ V ANDERNACHU ${ }^{1}$
}

\author{
On the Journey to Aachen. Hungarian Pilgrim Cross in Andernach
}

\author{
Jaroslav Nemeš
}

DOI: $10.17846 /$ CL.2020.13.1.83-101

\begin{abstract}
NEMEŠ, Jaroslav. On the Journey to Aachen. Hungarian Pilgrim Cross in Andernach. The study deals with the forked "Y-cross" from the 14th century which is now in the inventory of the Roman Catholic parish church of the Blessed Virgin Mary (Mariendom) in Andernach. The town became the main assembly point of Hungarian pilgrims heading for Aachen or Cologne (Köln am Rhein). Andernach is situated near the Middle Rhine stretch and pilgrims here were provided with free accommodation, sanitation and feeding from the 14th up to 18th centuries. Pilgrims, even from the Slovak part of the empire, were very thankful for that to citizens of Andernach. They are said to keep in the church crosses and flags that were later carried in processions. The unique gothic forked cross with the crucified Christ set the tone for a depiction of Saviour in the 14th century. Regarding the sacral relic, we do not know answers to basic questions. We do not know anything about its origin and background or fate. Therefore, we will seek answers for three basic questions: Why did Hungarian pilgrims assemble exactly in Andernach? What is the genesis of the Hungarian cross, respectively can we historically document its origin based on available sources? Can we determine its provenance based on typical features of its artistic style and details of its creation?
\end{abstract}

Keywords: history, Andernach, Aachen, pilgrims and pilgrimage, gothic cross, sacral art

\begin{abstract}
Abstrakt: NEMEŠ, Jaroslav. Na ceste do Cách. Uhorský pútnický kríž v Andernachu. Štúdia sa zaoberá vidlicovým „vetvovým“ krížom zo 14. storočia, ktorý sa dnes nachádza v rímskokatolíckom farskom Kostole Panny Márie v Andernachu. Mesto sa stalo hlavným zhromaždiskom uhorských pútnikov, ktorí smerovali do Cách (Aachen) alebo do Kolína nad Rýnom. Andernach sa nachádza na strednom Rýne, pútnikom tu poskytovali bezplatné ubytovanie, hygienu a stravovanie od 14. do 18. storočia. Pútnici, medzi nimi aj zo Slovenska, boli za to obyvatelom Andernachu vel'mi vdační. V kostole si vraj odkladali kríže a zástavy, ktoré potom brali do procesií. Jedinečný vidlicový gotický kríž s umučeným Kristom udal „tón“ zobrazovania Spasitela v 14. storočí. V súvislosti s touto sakrálnou pamiatkou nepoznáme odpovede ani na základné otázky. Nevieme nič ani o jeho pôvode, ani o jeho bližších osudoch. Budeme preto hladat odpovede na tri základné otázky: Prečo sa uhorskí pútnici zhromaždovali práve v Andernachu? Aká je genéza uhorského kríža, resp. je možné historicky doložit jeho pôvod na základe prameňov? Je možné určit jeho provenienciu na základe typických znakov umeleckého štýlu a detailov jeho vyhotovenia?
\end{abstract}

Klúčové slová: história, Andernach, Cáchy (Aachen), púte a putovanie, gotický kríž, sakrálne umenie

1 Štúdia je výsledkom riešenia projektu VEGA 1-0287-17 Založenie Uhorskej kaplnky v Cáchach králom Ludovítom I. 
Predložená štúdia sa bude venovat významnej sakrálnej pamiatke, gotickému vidlicovému krížu nazvanému uhorský, ktorý sa nachádza v meste Andernach. Kríž s názvom „Ungarnkreuz“ možno dnes vidiet v rímskokatolíckom farskom Kostole Nanebovzatia Panny Márie (Maria Himmelfahrt). Obyvatelia mesta tento chrám nazývajú Liebfrauenkirche alebo Mariendom. Pôvodný chrám, ktorý stál na jeho mieste už v 11. storočí, bol jedným z najvýznamnejších románskych kostolov v regióne Stredného Rýna. Viackrát bol prestavovaný a rozširovaný, dnes je chrám trojlod’ovou stavbou bazilikálneho typu (Keyser 1964, 52; Schneider 2012). Nachádzal sa v blízkosti stredovekých mestských múrov Andernachu a pri jednej z najdôležitejších brán mesta pri ceste, ktorá smerovala popri rieke do Kolína nad Rýnom.

Jedinečný vidlicový (vetvový) gotický kríž s umučeným Kristom udal „tón“ zobrazovania Spasitela v 14. storočí. V súvislosti s touto pamiatkou sa vynára viacero bádatel'ských tajomstiev. Nepoznáme jej pôvod, miesto vzniku, ani jej bližšie osudy. Cielom našej štúdie bude preto hladat' odpoved' na tri základné otázky: Prečo sa uhorskí pútnici zhromažd’ovali práve v Andernachu? Aká je genéza uhorského kríža, resp. je možné historicky doložit jeho pôvod na základe prameňov? Je možné určit jeho provenienciu na základe typických znakov umeleckého štýlu a detailov jeho vyhotovenia?

\section{Andernach ako zhromaždisko uhorských pútnikov}

Stredoveké mesto sa rozprestieralo v uzavretých hradbách na území s rozlohou asi šestnást̉ hektárov. Pútnici po stáročia prechádzali jeho centrálnou uličkou nazývanou Hochstraße, a to smerom od Koblenzu cez bránu Koblenzer Tor smerom k bráne Kölntor. Cesta od východnej brány (Koblenzer Tor) k západnému koncu (Kölntor) merala asi osemsto metrov (Keyser 1964, 52).

Mesto Andernach ležalo na dôležitej královskej ceste nazvanej Via Regia, prvýkrát spomínanej v roku 1234, ktorá spájala mestá Cáchy a Frankfurt (Aachen - Düren - Sinzig - Andernach Koblenz - Mainz - Ingelheim - Frankfurt). Známa bola už od čias Karola Vel'kého, lebo zbližovala jeho královské sídlo, palác s chrámom v Cáchach (nem. Aachen), s trhovým centrom Frankfurtom. Predstavovala vtedy najkratšie spojenie Cách a Frankfurtu cez Düren, Sinzig a Ingelheim, kde boli dalšie Karolove hradiská. Aj jeho otec Pipin III. cestoval z Dürenu do Andernachu a zo Sinzigu do Dürenu, ako to vyplývalo zo správ z rokov 748 a 758 (Neukirchen 2004, 126n.). Pobyty panovníkov v týchto lokalitách boli časté.

Historická královská cesta (Königsstraße) tiež stáročia slúžila ako hradská cesta pre vojenské účely (Heerstraße), no v stredoveku bola cesta významná aj tým, že tridsatkrát poslúžila korunovačným sprievodom z miesta volieb (Frankfurt) do miesta korunovácií (Cáchy). Bežný význam však mala hlavne pre kupcov a obchodníkov s tovarom smerujúcich na frankfurtský trh a jazdcov s poštou. Niekedy po nej cestovali i zámožnejší kúpelní hostia so svojimi sprievodmi (Schwartzenberg 2000, 17-23).

Via Regia patrila dĺžkou $252 \mathrm{~km}$ k najvýznamnejším dial'kovým cestám. Jedna jej vetva sa odpájala bud' pri Koblenzi alebo Andernachu a smerovala do Trevíra (Trier), druhá sa rozdvojila za Sinzigom a viedla cez Bonn do Kolína nad Rýnom (Schwartzenberg 2000, 9). Využívali ju i rôzni pocestní a pútnici, okrem iných i z Uhorského královstva. Zahraničná čast̉ púte Uhrov začínala vo Viedni. Skupinky zložené z dvoch - troch jednotlivcov postupovali popri Dunaji západným smerom k Pasovu (Passau), dalej smerovali na Norimberk a pri Rýne sa zoskupili do menších kŕdlov. Od Mohuča (Mainz) putovali vo väčších počtoch pri rieke Rýn a cez Koblenz smerovali až do $25 \mathrm{~km}$ vzdialeného Andernachu, kde bolo ich hlavné zhromaždisko, jedna z dôležitých pútnických staníc. $\mathrm{V}$ tomto meste im zvyčajne prvých štrnást̉ dní mesiaca máj bezplatne 
poskytovali fyzickú pomoc, menšie stravné, noclah a s malým cestovným ich prepustili na d’alšiu trasu (Terwelp 1884, 166; Bakó 1989 - 1990, 494). Kto bol chorý, dočkal sa tam aj zdravotného ošetrenia.

Za Andernachom sa cesta rozchádzala tromi smermi:

1) Do Kolína nad Rýnom a dalej do Cách uhorskí pútnici postupovali po dobre známej trase, ktorej čast’ ležala v porýnskej oblasti: Andernach - Sinzig - Bonn - Köln - Bergheim - Jülich Aachen. Pre malú čast' z nich boli konečným cielom samotné ostatky sv. Troch králov v Kolíne, väčšina ale pokračovala d’alej do Cách k Panne Márii.

2) Ak pútnici nešli do Kolína nad Rýnom, ale išli priamo do Cách cez Düren, ušetrili aspoň jeden deň cestovania v porovnaní s trasou cez Kolín nad Rýnom: Andernach - Sinzig - Bodendorf Eckendorf - Euskirchen - Düren - Aachen (Thoemmes 1937, 55nn.; Schwartzenberg 2000, 11; Neukirchen 2004, 127n.). Čulý pútnický ruch smeroval z Andernachu priamo do mariánskeho dómu v Cáchach. Vzdialenost’ od Andernachu k Eckendorfu, kde bola d’alšia prestávka na trase každodenného pochodu, bola $33 \mathrm{~km}$. V Dürene sa stretala cesta so spomínanou cestou od Kolína nad Rýnom (Thoemmes 1937, 58).

3) V smere do Trevíra vychádzala odbočka z Koblenzu alebo Andernachu, cesta viedla cez pohorie Eifel a pozdĺž údolia rieky Mosel. Pútnická cesta trvala asi osem dní, išlo zhruba o 160 km trasu (Blaeser et al. 2011, 14-17). Cielom pútnikov bol hrob sv. apoštola Mateja v Trevíre a následná poklona zachovanej tunike Krista. Z Trevíra potom mohli vykročit južným smerom cez Galíciu po svätojakubskej ceste, príp. nasledovat dalej do večného mesta Ríma.

Z uvedeného prehladu vyplýva, že Via Regia bola taktiež začlenená do siete velkých pútnických ciest smerujúcich do Kolína nad Rýnom (Traja králi) a do Santiaga de Compostela (Sv. Jakub). No najdôležitejšia bola táto cesta pre pútnikov smerujúcich do Cách (tunika Panny Márie a tri d’alšie látkové relikvie), resp. susedného Kornelimünsteru (tri látkové relikvie). Anglickí pútnici využívali túto cestu v oboch smeroch počas svojho putovania do Ríma alebo Jeruzalema, ako to vieme z jedného listu Karola anglosaskému královi Offovi (Neukirchen 2004, 126n.). O existencii starej pútnickej cesty zasa svedčí velký počet sakrálnych stavieb a drobných pamiatok, kaplniek a krí̌ov, napr. medzi Sinzigom a Dürenom, ktoré boli svedkami príkladnej zbožnosti viacerých generácií. Pre zabezpečenie starostlivosti o pútnikov bolo povedla starej cesty založených a vybudovaných množstvo hospicov, špitálov a zbožných podporných základín (Schwartzenberg 2000, 17; Neukirchen 2004, 126n.).

Bolo záujmom svetských aj cirkevných autorít, aby celá cesta Via Regia bola v poriadku, udržiavaná ako priechodná a v dobrom stave. Arcibiskupi i samotní pápeži apelovali na zhovievavost’ šlachty k financovaniu stavieb mostov, napr. cez rieku Mosel v Koblenzi, prípadne si stažovali, ked’ sa ich nedarilo opravovat. Hodnostári aj mestá sa starali o studne, o pramenitú vodu pre zástupy prechádzajúcich. No cesta slúžila, ako sme už spomínali, tiež vojsku, obchodníkom a bola využívaná i v časoch korunovácií (Schwartzenberg 2000, 9-13). Mala teda široký vojenský, hospodársky a kultúrny význam, bola jednou z najdôležitejších krajinských a hradských ciest.

Najstaršie správy o putovaní do Cách pochádzajú z 13. storočia. Od roku 1312 sa púte konali pravidelne a od roku 1349 sa slávnostné vystavenie štyroch hlavných látkových relikvií dialo každých sedem rokov (Schwartzenberg 2000, 15). Z rôznych politických príčin boli výnimkou iba roky 1580, 1636, 1797, 1916, 1923 a 1944, ked’ sa púte nekonali (Heizmann 1981, 119). Úcta ku Karolovi Vel'kému a početné relikvie zhromaždené v Cáchach, $\mathrm{z}$ ktorých mnohé zadovážil on sám, tam vyvolali čulý náboženský ruch. Podla Einharda, kronikára Karola Velkého, boli pútnici oslobodení od platenia mýta na všetkých brodoch, mostoch a riekach (Neukirchen 2004, 126n.). Uhorskí pútnici, medzi nimi i tí z územia súčasného Slovenska, sa chceli zúčastňovat pravidelných slávností v mariánskej svätyni a poklonit’ sa požehnaným látkovým relikviám. Cáchy sa tak stali pre Uhrov centrálnym pútnickým miestom do takej miery, že uhorský král L’udovít I. z Anjou založil v meste 
už v roku 1360 samostatnú uhorskú kaplnku a zriadil v nej dve kaplánske stanice, benefícium pre dvoch uhorských kaplánov znalých reči jeho poddaných (Nemeš 2019, 11n.).

A prečo sa stal Andernach pre uhorských pútnikov dôležitým miestom? Ako sme už spomínali, bol posledným spoločným zhromaždiskom pred ich rozdelením v smere na Cáchy, Kolín nad Rýnom a Trevír (ak tam už deň predtým neodbočili v Koblenzi). Navyše obyvatelia v Andernachu sa voči nim vždy zachovali priatel'sky a ústretovo. O zaopatrení uhorských pútnikov v Porýní sietou špitálov a noclahární napísal všeobecne historik Michel Pauly. Podla záverov jeho výskumov špitály plnili v čase púte do Cách funkciu ubytovní. Takmer v každej väčšej dedine či mestečku bola (najmä) pre uhorských pútnikov založená zbožná základina, alebo im miestny špitál otvoril svoje brány (Pauly 2007, 241-246). Vo vel'kej miere sa to dialo viacero storočí práve v Andernachu, čo si cudzinci rôznych národností prechádzajúci mestom bezpochyby museli vážit'. Špitály poskytovali pútnikom na ich ceste noclah a stravu.

Z predošlých základín vznikol v Andernachu na ulici Hochstraße v roku 1249 špitál sv. Mikuláša, ktorý dostal v roku 1485 novú budovu a v roku 1582 vynovenú kaplnku (Keyser 1964, 55). Od roku 1364 však tento starší špitál nebol zodpovedný za zásobovanie účastníkov púte z Podunajska do Cách a Kolína nad Rýnom, ktoré mali aj v Andernachu jednu zo zastávok, ale pre nich vytvorili špeciálnu základinu. Tieto takzvané „almužny na starom trhu“ (Almose auf dem Alten-markt), pomenované podla miesta domu almužien na starom námestí v rohu ulíc Kramgasse a Kleine Wollgasse (dnes Bahnhofstrasse), boli zriadené 30. apríla 1364 občiankou Andernachu Gertrud Fictors, vdovou po Heynemannovi von Kärlich. Ona zariadila testamentom, aby boli pútnici, ktorí „putujú k Panne Márii v Aachene“ počas svojho pobytu v Andernachu, „na večné časy“ potešení, osviežení a nasýtení (LHAK, B.612, 483, 484). Zbožná základina bola spravovaná andernachskými remeselníkmi. Výslovne bolo určené, že žiadny člen mestského senátu, urodzený človek, kňaz alebo rytier nemohli byt’ poverení jej správou. Táto základina odrážala napätý vztah, ktorý existoval v 60. rokoch 14. storočia v Andernachu medzi remeselníkmi a častou privilegovaných meštanov, ale tiež ukazovala, že starý špitál so starostlivostou často o niekol'ko stoviek ludí vrátane pútnikov, mohol byt’ očividne prełažený. Ako vidno z listiny z roku 1376, v ktorej sa hovorilo $\mathrm{o}$ „špitáli pre pútnikov a chudobných na Starom trhu v Andernachu“ (Pilger- und Armen-Hospital am Alten Markt zu Andernach), touto základinou povstal starému špitálu istý druh konkurencie. Ustanovizeň almužien zostala úplne nezávislá asi až do roku 1500 . V dokumente z 8 . januára 1510 sa však už o tomto mieste uvádzalo: „kde kedysi dávali almužny“. V tom čase teda už mladší špitál na námestí neexistoval. Správu zbožnej základiny prevzali najneskôr od roku 1538 majstri staršieho špitála na Hochstraße, ktorí boli od tohto roku zároveň menovaní „majstrami almužien“ (Almosenmeister) (Schäfer 2000, 62).

Aj ked’ obidve ustanovizne zostali na papieri aj nad’alej navzájom nezávislé, almužny „am alten Markt" boli mestskou radou odovzdané, takže uhorským pútnikom slúžili a starali sa o nich od 16. storočia v špitáli sv. Mikuláša na Hochstraße. Zatial čo sa o starostlivost’ o pútnikov postaral starší špitál, pohostenie sa pripravovalo skôr na konci mesta pri Kolínskej bráne (am Kölner Tor), kde bola pre nich špeciálne postavená kuchyňa. V písomnej agende špitála v Andernachu z rokov 1622/23, v ktorej zaznamenávali hlavne činnosti, ktoré vykonávali týždenne a ročne, sa tiež odvolávali na „Acher Heiltumbffardt“ (Schäfer 2000, 63). Počas púte častovali pútnikov z Uhorska, Kraňska a Chorvátska pri Kolínskej bráne pri východe z mesta, ned’aleko mariánskeho chrámu, v ktorom je dnes vystavený uhorský kríž.

Tu nám „Uhorský kríž“ v Kostole Panny Márie pripomína pútnikov, ktorí sem prišli nabrat silu pred telom Krista na zelenom strome života na dalšiu cestu do Cách. Pri Andernachu, kde boli zriadené základiny v ich prospech, sa zvykli zdržat dlhšie. Tu sa zachoval kríž a zástavy Uhrov (Neukirchen 2004, 127-128). Charitatívne záznamy z 15. až 18. storočia možno vyhladat v útrobách mestského archívu v dvoch fondoch, špitál a almužny (Heyen 1979, 171-186). Svedectvo 
o pomoci meštanov máme zachované $\mathrm{v}$ účtoch Hospitalrechnungen (LHAK, B.612, 14789) a Almosenrechnungen (LHAK, B.612, 14791, 14792). Medzi najčastejšie pútnikom rozdávané potraviny patrili v 16. storočí chlieb, hrach, fazula, rôzna zelenina, slanina, menej podávali mäso a syr, medzi nápoje zaradovali víno a pivo (Luschin von Ebengreuth 1878, 451).

\section{Uhorský kríž v prameňoch a literatúre}

Ani nám, ani žiadnemu inému bádatelovi sa nepodarilo nájst’ spomínaný tento konkrétny kríž $\mathrm{v}$ Andernachu v archívnych prameňoch alebo v literatúre pred 19. storočím. Historický výskum v Nemecku má za sebou už viac ako dvestoročnú tradíciu a je velmi úspešný. Je malá pravdepodobnost', že v budúcnosti by konkrétnu písomnú zmienku niekto našiel. Ako prvý napísal o „krížoch a vlajkách" uhorských pútnikov v roku 1838 znalec nemeckých dejín Friedrich Everhard von Mering. Tvrdil, že v Kolíne nad Rýnom putovali Uhri vždy pekne usporiadaní, v sprievodoch pod krížom a vlajkami, so spevom a modlitbami, aby v najvýznamnejšom kurfirtskom chráme pozdravili ústami a srdcom svätých Troch králov (Mering - Reischert 1838, 70). Zmienil sa o krestanských symboloch, ktoré nosili pri sebe.

Hlavný učitel a mestský knihovník v Cáchach Christian Quix v tom istom roku 1838 konštatoval, že 18. júla sa „Viedenčania“ zhromaždili o šiestej hodine ráno v katedrálnom kostole v Aachene a potom začali svoju procesnú spiatočnú cestu s krížom a vlajkou, a „tak odišli do Andernachu, kde umiestnili vlajku a kríž v miestnom kostole, až kým opät neprišli. To isté sa opakovalo každých sedem rokov, kým do Cách doputovali rovnakým spôsobom. V roku 1776 cisár Jozef II. zakázal svojim poddaným túto pút, ktorá sa zvrhla časom na žobranie“ (Quix 1838, 40).

Uhorské procesie nazývané „viedenské“ sa domácim javili ako „najskvelejšie a najslávnejšie“, ako prízvukoval v roku 1855 cirkevný historik a morálny teológ Heinrich Joseph Floss. Niektoré farnosti na Rýne mali ešte $\mathrm{v}$ tom istom roku funkčné základiny založené dávnejšie a pripomínajúce tieto procesie $\mathrm{z}$ juhovýchodu. $\mathrm{V}$ čase rozkvetu počet uhorských pútnikov dosahoval číslo pättisíc. „V Andernachu mali uložené svoje kríže a vlajky, pod ktorými pochodovali nádherným spôsobom do Kolína nad Rýnom, kde boli privítaní a bolo o nich postarané. Odtial odišli do Cách, kde boli zaopatrení na náklady dobročinných ustanovizní (Arm-Wienerspende) a jednotlivých kláštorov viacero dní. Jedlo im podávali ich oblúbené, ako sa zdalo, a to slaninu a hrach, pivo a pečivo. Pravidelne ponúkali i víno. V Kolíne obzvlášt uctievali svätých Troch králov“ (Floss 1855, 366n.; Stabéj 1967, 144n.).

O tom, že Andernach bol hlavným zhromaždiskom uhorských pútnikov smerujúcich do Cách, napísal ako prvý v roku 1878 numizmatik a historik práva Arnold Luschin, rodák z L’vova, ktorý študoval v Temešvári, pôsobil v Štajersku, Lublane a inde. Pútnici sa podla neho ocitli v meste Andernach v polovici mája, kedže po Rýne a po súši smerovali títo „Viedenčania“ priamo sem, do svojho stretávacieho miesta. Tu si v spomínanom farskom chráme nechávali kríže a zástavy, ktoré zakaždým pozdvihli, aby s nimi v slávnostných procesiách a so slovanskou piesňou na perách (windischen Liedes) 18. mája vtiahli do Kolína nad Rýnom (Luschin von Ebengreuth 1878, 453; 1887, 97). Uhorský kríž Arnold Luschin nespomenul, nevieme, z akého dôvodu, lebo ten sa konkrétne spomínal až v roku 1884.

Ako nás v roku 1884 informoval znalec umenia a andernachských dejín Gerhard Terwelp, uhorský kríž, ktorý pripomenul už pod týmto názvom, sa vtedy nachádzal v strednej chrámovej lodi mariánskeho chrámu oproti kazatel’nici. Vtedy to bolo tak, no v súčasnosti je umiestnený $\mathrm{v}$ presbytériu kostola na jeho konci, $\mathrm{v}$ uzávere pri stene. Terwelp tvrdil, že podla tradície ho najneskôr do polovice 14. storočia priniesli Viedenčania, ako týchto cudzích pútnikov nazývali (Terwelp 1884, 166; Luschin von Ebengreuth 1878, 439). Boli to skupiny Uhrov a Slovanov, ktorí každých 
sedem rokov prechádzali mestom Andernach. Medzi nimi sa nachádzali aj pútnici zo Štajerska, Korutánska a Kraňska (Luschin von Ebengreuth 1878, 440). V novoveku k nim pribudli taktiež skupiny Slovincov a Chorvátov (449). Vo vel'kom počte putovali do Cách, ale i do iných náboženských centier, do Kolína nad Rýnom, Trevíra, Prümu a inde, aby sa poklonili vzácnym relikviám (Terwelp 1884, 166; Bakó 1989 - 1990, 494). Stovky, často tisíce pútnikov z Uhorska prichádzali na pút do Cách každých sedem rokov. Bolo medzi nimi aj mnoho chudobných, hladných alebo chorých ludí, o ktorých sa bolo treba na ceste postarat. Dôvod, prečo kríž nesie meno „uhorský', nemohol byt známy. Terwelp to pripisoval dlhej tradícii putovania do Cách medzi uhorskými krestanmi. O minulosti uhorského kríža nič konkrétnejšie povedat’ nevedel, ale v Andernachu zvykli, podla neho, odkladat či uschovávat svoje kríže a zástavy, ak ich mali pri sebe pri slávnostných procesiách. V tomto meste si totiž robievali dlhšiu prestávku. Cestou spievali svoje domáce nábožné piesne a do Kolína nad Rýnom sa dostali 18. mája (Terwelp 1884, 166; Thoemmes 1937, 67n.; Bakó 1989 - 1990, 494). Nemožno preto vylúčit', že by ho Uhri mohli priviest’ do Andernachu so sebou (Schneider 2012). Preto podla starších správ dostal ludový názov Ungarnkreuz a patril $\mathrm{k}$ typu morového kríža. Začiatky sú $\mathrm{v}$ hmle, ale dnes je táto pamiatka jednou $\mathrm{z}$ najdôležitejších sakrálnych pamiatok mesta Andernach a strednej časti Porýnia.

Kňaz a jezuita Stephan Beissel publikoval v roku 1902 záslužnú prácu o histórii pútí do Cách. Pomerne vela priestoru venoval i uhorským pútnikom. Andernach však spomenul iba okrajovo, a to $\mathrm{v}$ súvislosti $\mathrm{s}$ tým, že $\mathrm{v}$ tomto porýnskom meste mala kapitula $\mathrm{v}$ Cáchach väčšie pozemkové vlastníctvo. V roku 1364 tam vdova Gertrude Fictors založila základinu v prospech pútnikov. Uhri si tam uchovávali kríže a zástavy, vzali ich a dolu Rýnom sa presunuli do Kolína, kde sa im dostalo priatel’ské prijatie. Zdrojmi pre jeho tvrdenie bola staršia literatúra, žiadne archívne pramene neuviedol (Beissel 1902, 90).

Ďalšou autorkou, ktorá na existenciu uhorského kríža upozornila v odbornej literatúre, bola historička Elisabeth Thoemmes. V roku 1937 publikovala monografiu o putovaní Uhrov do oblasti Rýna, v ktorej uverejnila aj obrázok tohto kríža (Tafel IV). V krátkom texte o ňom sa stotožnila so závermi Gerharda Terwelpa z roku 1884. Pripustila, že hoci písomné pramene ku krížu zachované nemáme, predošlí autori vychádzali z miestnej ústnej tradície, ked’o ňom hovorili ako o uhorskom. Nosili ho do Cách na čele procesií a po zákaze pútí zostal vraj stát v kostole v Andernachu (Thoemmes 1937, 66-68).

V období druhej svetovej vojny bola táto oblast’ Rýna dejiskom tažkých bojov, známe sú udalosti v nedalekom Remagene. Dlhšie trvalo, kým sa vojnové škody odstránili. Kríž bol v roku 1953 zreštaurovaný, z pohladu dneška nie velmi vhodne, zdokumentovaný a umiestnený v presbytériu kostola. O jeho sprístupnení podal správu v nasledujúcom roku kunsthistorik a akademik Eduard Trier (1954, 93nn.; obr. 3 na s. 99), ktorý ho aj stručne charakterizoval a priniesol i obrazový materiál.

Ďalšie publikácie o dejinách mesta fenomén pútnictva vôbec nespomínali, takže žiadne nové skutočnosti nepredložili (Adams 1955; Rosch 1955; Fischer 2008). A tí autori, ktorí ho neopomenuli, viac-menej opakovali v 19. storočí publikované fakty. Prípadne spresňovali datovanie, resp. ho podrobnejšie skúmali z umenovedného hladiska a hladali jeho analógie.

Slovinský vedec Jože Stabéj, ktorý sa v roku 1967 zaoberal históriou pútí Slovincov do Cách, rovnako tvrdil, že pútnici do Cách a Kolína si pútnický kríž a zástavy uschovávali v Andernachu, kde si museli na ceste tam aj spät urobit zastávku (142). Konkrétny kríž však nespomínal.

Archivár biskupského archívu v Cáchach Dieter Wynands, známy mnohými publikáciami o miestnych pútach, vyšiel v roku 1986 so zaujímavou teóriou. V jednej zo svojich monografií tvrdil, že uhorskí pútnici si v kostole v Andernachu uložili kríž a zástavy pri svojom poslednom putovaní. To bolo v roku 1769. Ich kríž prežil dodnes v „búrkach časov nepoškodený“ (76). Konkrétny zdroj tejto informácie však neuviedol. 
Riaditel múzea a znalec dejín mesta Andernach Klaus Schäfer vymedzil obdobie vzniku kríža na začiatok 14. storočia. Kríž bol podla neho darovaný farnosti pútnikmi z Podunajska z vd’aky za ubytovanie a stravovanie počas pútí. Napísal to v roku 1996 (70).

Helmut Weinand, autor posledného turistického sprievodcu po Kostole Nanebovzatia Panny Márie z roku 2012 uviedol, že kríž pochádzajúci zo začiatku 14. storočia nazývali uhorským, morovým, zázračným či vidlicovým. Uhorskí pútnici ho darovali domácim za to, že ich každých sedem rokov prijali a pohostili, ked’ putovali do Kolína a Cách. Nakoniec konštatoval, že tento kríž je skoro rovnaký (fast gleich) ako spomínaný kolínsky vidlicový kríž z kostola na Kapitole (10).

\section{Kríž z Andernachu ako modelový príklad vidlicových krížov 14. storočia}

Viacerí autori sa zamýšlali a rozoberali typológiu tohto druhu krížov, resp. korpusov Krista. Konštatovali, že ide o vetvový vidlicový kríž, ktorý bol v staršej literatúre širšie datovaný do prvej polovice 14. storočia, resp. medzi rokmi 1300 - 1350. Nesporné bolo, že zobrazoval umučené telo Krista vo vrcholne gotickej podobe pripevnené na rozdelenej vetve stromu. Priekopníckymi sa ale stali až moderné nedávno vydané práce. Ich úlohou bolo tiež spresnit’ staršie datovania.

Ako prvý z umenovedného hladiska o kríži informoval spomenutý Gerhard Terwelp (1884). Podla neho kríž očividne vykazoval cudzorodý umelecký charakter. Charakterizoval ho ako velký vidlicový kríž v tvare gréckeho písmena Psí, porovnával ho s Gabelcrucifixom umiestneným v minoritskom kostole v Kolíne nad Rýnom alebo s krížom v Kostole Panny Márie na Kapitole v tom istom meste. Opísal ho nasledovne: Hlava Krista s tŕňovou korunou je velmi naklonená do pravej strany, ale aj hlboko schádza na nadmerne vystupujúcu hrud'. Spasitel nie je zobrazený ako živý alebo dokonca umierajúci, ale je zastúpený už ako mŕtvy a považovaný za mútveho. V dôsledku toho sa celá horná časț tela ohýba dopredu, ako keby chcel vypadnút z toho kmeňa. Kmeň a vetvy kríža sú hrčkovité a pokryté kôrou. Bedrová plachta, ktorá je spustená a zvlnená na oboch stranách, sa tiahne od bokov až po kolená. Pod nohami si môžeme prečítat nápis Renovatum 1671. A na záver konštatoval: „Ale namiesto toho, aby dojem z kríža bol ideálny a povznášajúci, telo ukrižovaného je príliš realistickou prezentáciou utrpenia Spasitela a takmer odstrašuje“ (Terwelp 1884, 167; Bakó 1989 - 1990, 495).

Ku korpusu z Andernachu sa dvakrát vyjadril v časopise Zeitschrift für christliche Kunst umenovedec a riaditel’ múzea Fritz Witte (1920, 123n.; 1921, 24n.). Prezentovanie kríža na vtedajšej výstave mu totiž umožnilo jeho bližšie a detailnejšie preskúmanie. Witte si na kríži v Andernachu všimol niekol'ko náznakov predchádzajúcich intervenčných výplní. Ak bol na jeho brvne napísaný dátum Renovatum 1671, potom sa podla neho mohol týkat iba novej polychromizácie, novšej pozlátenej kovovej tŕňovej korunky a konsolidácie lavého predlaktia. Zdalo sa mu, že nová polychrómovaná verzia prikryla primerane zachovanú, omnoho lepšiu pôvodnú malbu, ktorú by mal opät prinavrátit’ spät zručný reštaurátor. Konštatoval, že uhorský kríž patril podla staršej tradície k velkej skupine na západe Európy zachovaných realistických krížov, z ktorých všetky pochádzali z prvej polovice 14. storočia. Spolu s inými boli vytvorené pod vplyvom silných emocionálnych otrasov okolo roku 1300 - v dôsledku hnutia flagelantov (trpitelov), prepuknutia čiernej smrti - moru a všeobecného strachu z konca sveta $\mathrm{v}$ roku 1300. Do tohto istého radu patrili podla neho aj tri kolínske kríže z kostolov sv. Severina, sv. Jakuba a Panny Márie z Kapitolu (Witte 1921, 24n.).

Fritz Witte priniesol zaujímavé názory o pôvode vidlicových krížov. Velká skupina týchto krížov nachádzala podla neho vysvetlenie iba v náboženskej kultúre svojej doby, ktorá bola silnejšia a osobitejšia než ktorákolvek iná doba stredoveku. Obdobie dvoch desatročí prelomu 13. a 14. storočia považoval za obdobie vzniku všetkých podobných krí̌ov. Podla neho dokumentovali slobodu počínania umelcov konca 13. storočia a vypracované emócie ich umeleckého temperamentu, 
ktorý by mal byt príkladom a stimulom aj pre všetkých v súčasnosti nábožensky tvoriacich umelcov. Jedna otázka mu však stále nedávala spávat: išlo o rozšírenú náboženskú koncepciu, ktorá zároveň naliehala na nové formovanie obrazu Spasitela, alebo bol východiskový bod položený na nejakom mieste, za ktorým možno hladat pútnické miesto? Táto druhá domnienka sa mu natískala sama o sebe, ak si vzal pred oči príklady krížov z Andernachu a z Kolína nad Rýnom. Pokial' však išlo o skupinu krížov zachovaných severnejšie od Kolína, takáto odpoved’ sa mu nezdala dobrá, vzhladom na nevýznamné odchýlky medzi nimi (severnými) a kolínskymi. Dôležité podla neho bolo, že takmer s každým krížom boli spájané staršie legendy a súčasne sa na ne vztahovali príklady ich zázračnej moci. Witte dodáva, že to bolo takmer podobné ako v prípade krucifixov, ktoré rolníci ešte stále zvesujú pomocou kladky zo steny (išlo o rok 1920) a ktoré potom s modlitbou na perách „vliekli“ šestkrát okolo kostola, akonáhle niektorý človek v obci vážne ochorel a bojoval so smrtou. „V Coesfelde, kde majú takýto kríž, sa ešte dnes (1920) tohto držia a slávnostne tam s ním putujú, aj v Andernachu a inde" (Witte 1920, 123n.).

Kríž z Andernachu bol podla Fritza Witta v realizme pravdepodobne najsurovejší a najsilnejší. Tvrdil, že Terwelpov názor bol správny, že tento kríž bol kedysi darovaný andernachskej farnosti pútnikmi z východu, ktorí mestom často od 14. do 18. storočia prechádzali v zástupoch. Cudzorodo vyznievali podla neho oba krucifixy, kolínsky z Kapitolu a andernachský, a bolo mu zrejmé, že „pri premýšlaní o ich pôvode sa treba orientovat na juh alebo slovansky ovplyvnené krajiny" (Witte 1920, 123n.). To ho utužilo v názore, že pamiatku mali v Andernachu nechat’ pútnici z Uhorska.

$\mathrm{V}$ tom čase začali i autori a znalci umenia $\mathrm{z}$ iných krajín analyzovat tento typ vidlicových krížov. Začali tie svoje porovnávat so zachovanými z okolia Kolína nad Rýnom. Okrem kríža z Jihlavy to boli i pamiatky zachované u nás na Spiši.

Podla staršej práce prešovského rodáka, kňaza a muzeológa Kornela Divalda z roku 1906 spadali tieto kríže, rovnako ako kríž z bočnej steny kostola v Poprade-Matejovciach, podla ich velkosti do kategórie prenosných sprievodných krížov, ktoré sa používali po stáročia v procesiách a často boli premalovávané. Samotný vidlicový kríž z Matejoviec datoval až do prvej polovice 15. storočia. Datovanie mu však nesedelo. Ako uviedol, zástera, ktorá obklopovala boky Krista, dosahovala po kolená, bola reminiscenciou na románsku dobu. V ukrižovaní videl výraz Kristovej tváre, ktorý odzrkadloval jeho smrtelné vyčerpanie bezprostredne po smrti (Divald 1906, 39, tam pozri aj vyobrazenie kríža).

Mad’arský umenovedec Antal Kampis sa v roku 1932 zaoberal i krížom visiacim v kostole v Matejovciach. Snažil sa ho porovnat so skupinou krucifixov z Kolína nad Rýnom, ku ktorým priradil aj viaceré kríže z okolia. Z nich bol najdôležitejší andernachský. Až do Kampisovej súčasnosti boli všetky tieto kolínske krucifixy datované do roku 1400, ale vtedajšie najnovšie výskumy plastiky z kolínskeho Kapitolu ich posunuli na úplný začiatok 14. storočia (Kampis 1923, 49).

Kampis (1923, 50n.). priniesol aj zaujímavý názor svojho súčasníka, frankfurtského umenovedca Frieda Lübbeckeho, ktorý vo svojej práci Die Plastik des Deutschen Mittelalters uviedol, že všetky krucifixy v Kolíne a jeho okolí boli ludovo nazývané Ungarnkreuz, čo dokazuje tiež pomenovanie krížov zachované v rôznych mestách. Duch a forma kolínskych krížov podla neho úzko súvisela s matejovským krížom. Najbližšie k matejovskému bol práve andernachský Ungarnkreuz. Tento kríž podla neho zachovával pôvodné znaky „Arbor Vitae“, zatial” čo väčšina sliezskych krížov vykazovala už novšie znaky. Pod vplyvom staršej kolínskej skupiny pamiatok sa na severe Sliezska vytvorila druhá skupina, sliezska, z ktorej najstarší kríženec visel v Chráme sv. Martina vo Vroclave, autenticky datovaný do roku 1322. Predpokladal, že pod vplyvom umeleckých diel z Kolína nad Rýnom vznikla skupina krížov v Uhorsku v rovnakom čase ako tá v Sliezsku, z ktorej, žial, podla neho, prežil len jediný kus, ten matejovský zo Spiša. Uhorsko a Sliezsko mali v stredoveku velmi tesné vztahy, čo je historicky zdokladované. Na záver ale 
Kampis (1923, 51n.) tvrdil, že v Uhorsku vzniknutá skupina bola autochtónna, nezávislá od sliezskych príkladov, a bolo v nej možné vidiet prežívajúce relikty uhorskej pamätovej kultúry vyvinutej samostatne v 14. storočí.

O tomto type krížov zachovaných na Spiši napísal v roku 1948 i slovenský umenovedec Vladimír Wagner. Tvrdil, že rezbárska tvorba v prvej polovici 14. storočia vychádzala z expresívnosti výrazu. Ako príklad uviedol skupinu votívnych krížov zo Spiša „s typickým plošným a lineárnym chápaním rúcha vo fyzickej forme, preexponovaným výrazom vnútorných afektov a krížom vidlicového tvaru, vyhotovených pod vplyvom krížov porýnskeho okruhu a motívmi umenia sliezskeho a podunajského“. Za vyspelého reprezentanta týchto krížov označil kríž z Matejoviec, ktorého výrobu datoval okolo roku 1320 a ktorý dnes visí na severnej stene chrámu. Spomína aj „jeho derivát“ v Lendaku s datovaním pred polovicou 14. storočia. Tento typ krížov sa podla Wagnera udržal počas celého 14. storočia. Ich štýlovú premenu vykazovali aj kríže z Levoče (okolo 1360 - 1370) a zo Spišských Draviec a „kamenné sochárstvo ho uplatňovalo ešte začiatkom 15. storočia v Košiciach“ (Wagner 1948, 25, obr. 22 v prílohe). Wagner (1948, 25n., obr. 18 v prílohe) myslel konkrétne na reliéf ukrižovania vo františkánskom kostole v Košiciach zhotovenom po roku 1406.

Mad’arský umenovedec Dénes Radocsay v roku 1967 velmi pekne vystihol problematiku identifikácie diel stredovekého umenia. Hoci boli umelecké školy maliarov a rezbárov stredoveku podla neho navzájom prepojené, mali i mnoho lokálnych charakteristických čŕt. Dôležité miesta gotiky 14. storočia boli síce nejakým spôsobom usporiadané, ale vývoj medzi nimi často preskočil. Heterogénne prvky nejakého štýlu sa mohli lahko objavit’ v tesnej blízkosti vedla seba v priestore a čase, ale nepriamo sa mohli využit i vo väčších vzdialenostiach a v inom čase, bez preukázania ich skutočného vztahu. Preto je podla neho tažké určit pôvod gotických diel (Radocsay 1967, 22).

Korpus z Matejoviec je podla Radocsaya $(1967,22)$ vyzretou gotickou plastikou s ušlachtilými vlastnostami spišskej školy 14 . storočia. Ide o majstrovské dielo nového vývojového obdobia. Telo Krista trpiace ludským utrpením visí strmo so skríženými nohami. Pravá noha prekrýva na priehlavkoch lavú. Ježišove ruky nesú celú zátaž umučeného tela. Hlava je mierne naklonená dopredu, trup sa nakláňa do strany. Neznámy umelec zobrazil posledné utrpenie mŕtveho muža $s$ realistickou úprimnostou bez toho, aby sa pri vykreslovaní smrtelných bolestí opieral o prehnaný expresionizmus známych krížov z Kolína nad Rýnom (St. Maria im Kapitol), Coesfeldu alebo z Andernachu. Tu sme pri koreni veci - kríž z Matejoviec a príbuzný kríž z Lendaku nemali podla neho priamy súvis s vidlicovými (vetvovými) krížmi kolínskeho a sliezskeho okruhu.

Matejovský kríž publikoval Divald, ako sme už spomínali, a opakovane sa mu venovala aj literatúra. Jeho datovanie, odhliadnuc od Divalda, kolísalo medzi rokmi 1320 a 1400. Jeho typ a forma upútali pozornosṫ už dávno. Dénes Radocsay (1967, 16n., obr. 6) napísal, že kríž v Matejovciach pochádzal z rokov 1330 až 1360. Uviedol, že Antal Kampis ako prvý rozpoznal jeho „príbuzných“ v sliezskom a rýnskom umení, ktoré sa v Kolíne nazývali Ungarnkreuz. Pôvod tohto názvu bol však i podla Radocsaya nejasný, lebo pôvod krížov tohto typu s východnými nemal nič spoločné. Totiž v Andernachu sa nachádzal pravdepodobne procesný kríž uhorských pútnických sprievodov. Neexistuje však žiadna stopa pomenovania Ungarnkreuz pred 19. storočím, ked’ sa púte ešte konali. Častý výskyt pojmu v literatúre a závery, ktoré sa na základe nej vytvárali, boli pravdepodobne dôsledkom štúdie Gerharda Terwelpa o korpuse v Andernachu. Kampis správne prepojil štýl kríža z Matejoviec so simultánnymi sliezskymi prácami a správne zdôraznil, že naše dielo je, napriek jeho sliezskym súvislostiam, nepopieratelne samostatnou prácou. Jeho blízka analógia ani nie je známa, korpusy zo 14. storočia nie sú priamo porovnatel’né s korpusmi z 15. storočia, iba v hrubých obrysoch. Mladšia rezba je plynulejšia a schematickejšia. Západné mystické rezby vyrobené v roku 1300, alebo $\mathrm{v}$ prvých dvoch desatročiach 14. storočia, sa vyznačovali vášnivým a dekoratívnym naturalizmom. „A zatial čo móda kolínskych mystických krížov sledovala celý 
chronologický vývoj, krížiky vyrobené po tridsiatych rokoch 14. storočia mali jemnejšie štylistické črty, ako bolo napríklad jemnejšie vlnenie bedrového rúcha, dekoratívnejší vzorec tela, stále sa vzdalovali od kolínskeho typu, “ konštatoval Radocsay. „Kedže pôvodná surová podoba týchto krížov sa postupne zmierňovala mladšími desatročiami 14. storočia, ich kŕčovité formy sa zmäkčovali a zjemňovali väčšou geografickou vzdialenostou od miesta zrodenia tohto typu a vplyvmi južného umenia." V nasledujúcich desatročiach sa k ikonografickému typu pripojili dalšie tri spišské kríže, z Levoče, zo Spišských Draviec a neskôr zo Spišskej Belej. Dénes Radocsay tvrdil, že boli nasledovníkmi uvolnenejšieho, miernejšieho štýlu, rovnako cudzie vášni i expresionizmu staršieho západného typu (Radocsay 1967, 22).

Nemecký umenovedec Joachim Glatz (1984) o tomto type krížov napísa,l že vdaka svojmu umeleckému výrazu má Ungarnkreuz v oblasti umenia zvláštne miesto. Vznikol v prvej polovici 14. storočia a patril do skupiny morových krížov. Ukrižované Kristovo telo bolo napnuté na trojvetvovom kríži.

V kolektívnej monografii mesta Andernach z roku 1988, ktorú zostavil archivár Franz-Josef Heyen (1988, 188n.), bol kríž datovaný okolo roku 1320. Autori sa vyjadrili v prospech názoru, že pomenovanie Ungarnkreuz bolo tradované od 19. storočia, lebo staršie zmienky nie sú známe. Spojenie s dávnejšími pútami Uhrov idúcimi do Kolína nad Rýnom a Cách nie je podla nich dokázatel’né. $V$ diele je ale gotickému krížu venovaný minimálny priestor.

Najnovšiu charakteristiku Crucifixus dolorosus v Liebfrauenkirche Andernach podal v roku 2006 umenovedec, historik a teológ Godehard Hoffmann. V unikátnej obrazovej monografii sa venoval skupine vidlicových krížov s bolestným korpusom z celoeurópskeho hladiska komplexne (Hoffmann 2006, 60-64). Zistil, že krucifix z Andernachu možno pripísat k postupnosti línie kríža z kolínskeho Kapitolu. Vedecký prístup k podobnej pamiatke je však zložitý, pretože na jednej strane nemáme o ňom zachované takmer žiadne písomné správy, a na druhej strane jeho stav bol zakrytý opakovanými, čiastočne nevhodnými výplňami. Citoval pri tom Birgit Ernstberger, ktorá ukončila štúdium na Fachhochschule Köln diplomovou prácou (2002) o tejto pamiatke. V nej predstavila vykonanú drevársku a technickú prehliadku, ktorou odstránila mnohé naše nevedomosti (Hoffmann 2006, 60).

Pôvod kríža a jeho staršia história ležia v hmle. Od konca 19. storočia bol známy pod názvom Ungarnkreuz. Andernach bol od konca stredoveku zhromaždiskom uhorských pútnikov, ktorí sa odtial' presúvali do Kolína nad Rýnom a Cách, aby si tam uctili mnohé relikvie. V roku 1769 cisár Jozef II. im tieto púte zakázal. V 19. storočí vznikla potom myšlienka, že uhorskí pútnici nosili Crucifixus dolorosus z Andernachu do Kolína nad Rýnom a naspät. Dokonca sa Uhorsku pripisovalo vlastníctvo diela. Ale Hoffmann zdôraznil, že táto tradícia nie je podporená nijakými zdrojmi. Históriu Andernacher Kreuz preto musíme považovat’ za nedoriešenú (Hoffmann 2006, 60).

Hoffmann detailne komentoval jeho umelecké vyhotovenie. Umučené telo ukrižovaného Krista visí na troch pripevnených klincoch s mierne vyčnievajúcim pravým kolenom na krízii. Hlava je naklonená úplne doprava, takže krk je takmer vo vodorovnej polohe. Zdôrazňuje sa rebrová klenba s vyčnievajúcimi rebrami, brušná stena výrazne klesá. $Z$ otvorenej bočnej rany na pravej strane hrudníka prúdi krv hustými kvapkami. Prekrížené chodidlá sú typickým znakom Crucifixi dolorosi: na prednej nohe je koža natrhnutá smerom nahor, tým sa uvolnil pohlad na krvavé šlachy. S najväčšou pravdepodobnostou boli aj na rukách také rany, ale nezachovali sa, pretože ruky sú moderným doplnkom. Kristova tvár vyjadruje moment smrti. Brada z dreva je vypracovaná a ozdobená. Prechod nosa k tvári je formovaný tromi zakrivenými záhybmi, ktoré sú d’alšou charakteristickou črtou krucifixu z kolínskeho Kapitolu. Tento špecifický motív vytvára vztah - dôležité spojenie s kolínskou výrobou. Bedrová plachta poukazuje na velmi krásnu látku, ktorej estetický vzhlad je v nápadnom kontraste s drastickými znakmi utrpenia. Vieme tiež, že na kolínskom kríži z Kapitolu je bedrová plachta svojím dizajnom celkom odlišná. Pred bruchom 
je horizontálne modelovaných niekol'ko záhybov, na stehná preto padá látka hladšie. Uchá na textilnej látke sú modelované tak, že visia ako bočné na bokoch v určitej vzdialenosti od tela. Vysoko kvalitný dizajn bedrovej tkaniny je dnes spôsobený novším vyhotovením, ktoré nie je na prvý pohlad viditelné. Pôvodne bola vnútorná strana šatky pokrytá drahým azuritom, ako na tom kolínskom kríži. Tam, kde sa vonkajšia strana látky priamo prekrývala s otvorenými častami látky vo vnútri - rovnako ako na bočných rohoch - musel byt výrazný farebný kontrast.

Ukrižovaný muž visí na rozvetvenom dreve kríža. Na kmeni a vetvových ramenách sú viditel'né výrastky mladých vetiev, ktoré sa objavujú ako púčiky z kôry a po niekolkých centimetroch boli zrezané. Nad hlavou visí drevený vyrezávaný titulus s nápisom INRI. Krížový kmeň sa bočne orezáva na spodnom konci, čo bolo dôsledkom jeho zapadnutia do rukáva železného stojana, v ktorom bol zasunutý, a dodnes stojí v centrálnej apside Kostola Panny Márie. Tri železné klince na ranách sa môžu považovat̉ za pôvodné (Hoffmann 2006, 60).

Hoffmann zverejnil tiež výsledky odborného preskúmania. Výška tela sa meria od špičiek chodidiel po končeky prstov $102 \mathrm{~cm}$, a teda presne zodpovedá rozmerom kríža v Bocholte. Rozpätie ramien meria asi $78 \mathrm{~cm}$. Kríž má výšku $140 \mathrm{~cm}$ a rozpätie ramien $84 \mathrm{~cm}$. Telo bolo vyrezávané od nôh ku krku z jelšového dreva (mladšie ramená môžu zostat nepovšimnuté, ich dreviny sa nedajú určit'). Drevina bola v tomto čase v regióne neobvyklá. Husté kvapky krvi pod bočnou ranou boli vyrezávané z dreva. Hlava bola osadená osobitne a pozostávala z orechového dreva. Na dosiahnutie jej silného sklonu sa do zadnej časti krku vložil klin. Upevnenie hlavy bolo vykonané pomocou lepidla a dvoch silných železných klincov. Na pleciach a vlasoch je vidiet', že tam bolo viac prameňov vlasov, ako tam zostalo dnes, čo výrazné poškodzuje vzhlad plastiky. Hrudník bol zo zadnej strany vyhĺbený a uzavretý dvoma doskami, ktoré pravdepodobne tiež vyrobili z jelše (nie je to možné preukázat'). V dutine spočívalo ukryté plátno so zvyškami kostí, ktoré nie je možné identifikovat. Röntgenové lúče vykazovali najmenej sedem kúskov kostičiek. Titulus bol vyrezávaný z lipového dreva, je považovaný za originálny, ale pochybnosti o tom môžu byṫ. Drevo kríža bolo vyrobené z jedle. Na nej bol zapísaný rok renovácie 1671. Na hlave Krista bola tŕňová koruna z kovu, určite to však nie je originál, ktorý sa stratil (Hoffmann 2006, 62).

Birgit Ernstberger dokázala identifikovat pät prekrývajúcich sa vyhotovení na korpuse a šest’ prekrývajúcich sa vyhotovení na kríži. Ich interpretácia je ale zložitá, pretože obnova vykonaná v roku 1953 s vystavením korpusu viedla k vážnym škodám. Pôvodná verzia však nie je medzi neskoršími vrstvami zachovaná. Telo je pomerne hladké, teda musíme predpokladat, že pôvodná verzia bola nenávratne skresaná (Hoffmann 2006, 62).

Andernachský krucifix sa v literatúre označuje ako velmi blízky k tomu na Kapitole v Kolíne nad Rýnom. Medzi základné charakteristiky, ktoré ho spájajú s ním a jeho nástupníckymi prácami - a preto boli spolu s ním oprávnene zoskupené do kolínskej skupiny - patrí postoj ukrižovaného s natiahnutým pravým kolenom, ozdobne koncipované rebrá, hlava naklonená dopredu a roztrhané rany a nechty na nohách. Koniec koncov, ukrižovaný Kristus z Andernachu má tiež tri nápadné záhyby v blízkosti nosnej kosti známe z Kapitolu, čo sme už spomínali. Existujú však aj rozdiely: andernachský krucifix nemá jemne diferencovanú plasticitu tela kapitolského kríža a telo nie je mučením zakrivené (Hoffmann 2006, 63). Velmi krásna bedrová látka bola zložená z menších kúskov a bola bližšie k telu.

Hoffmann koncipoval významné závery. Zrejmé prepojenia aj rozdiely medzi kapitolským krížom a krížom z Andernachu neznamenali dielenské spojenie, ale znalost̉ kolínskej práce u rezbára z Andernachu. Andernachský kríž sa svojou vel'kostou, celkovým dizajnom, hrudníkom s čírym hrudným kuželom a jasným vymedzením brucha cez koncepčné výklenky vyznačoval podobnostou s krížom v Bocholte. Kríže v Andernachu a Bocholte boli však medzi sebou natolko odlišné, že nepočítame s tým istým rezbárom. Celkovo bol kríž v Bocholte bližšie ku kapitolskému ako andernachskému. $\mathrm{V}$ oboch prípadoch išlo o následné práce s neznámym časovým intervalom, 
pričom kríž v Andernachu sa mohol objavit’ o niečo neskôr ako bocholtský. Predošlí autori považovali obdobie rokov 1310 - 1320 za obdobie vytvorenia kríža v Andernachu, Hoffmannovi (2006, 64) sa to ale zdalo trochu skoro a priklonil sa $k$ druhej štvrtine 14. storočia.

Godehard Hoffmann dokázal velký vplyv vychádzajúci z kríža v Kostole Panny Márie na kolínskom Kapitole, ktorý sa prejavil v rezbárskej tvorbe v Porýní po roku 1310 až do polovice 14. storočia. Pri svojej komparácii vychádzal z poznania takmer všetkých európskych krížov, i toho z Jihlavy, ktorý k rýnskej skupine nepriradil, no nepoznal spomenutý kríž z Matejoviec a ani d’alšie spišské práce.

Definíciu bolesti obsiahnutú v tomto type bolestných krížov z prvej polovice 14. storočia priniesla Anne-Rose Meyer (2011, 205, pozn. 24), pričom ako ukážkový príklad spomenula práve kríž z Andernachu. Podla nej snaha o vyjadrenie utrpenia predurčila obsah a formu umeleckého zobrazenia. Pohnútku vedúcu k zbožnosti človeka dotvárala zvýšená drastickost̉ obrazu, umučenie a smrt' Krista viedla k fyzickej deformácii jeho tela. Vykreslenie plasticity Božieho tela sa stalo viac dôležitým. To, čo sa predtým nazývalo sviatostným, sa teraz využívalo na dramatické a mystické zveličenie: krv vytekala $\mathrm{z}$ rán často po dlhých krvných stopách tahaných cez celé časti tela. Farba zvýrazňovala jednotlivé detaily velmi realistickým spôsobom.

Zo slovenských autoriek tento typ krížov naposledy analyzovala Mária Spoločníková, známa odborníčka a reštaurátorka gotického umenia. Konštatovala, že na rozdiel od predchádzajúceho 13. storočia sa v 14. a 15. storočí posunulo tažisko pojmovej výpovede kríža ku dramatickému výrazu tela Krista ako dominujúcej zložky. Teda s akcentom na utrpenie bolestou znetvoreného a utýraného ludského tela. „Dynamický vzruch bolesti vyústil do základov expresívneho až mystického vrcholu. "Podla nej ide o tzv. mystické kríže, lignum vitae, arbor vitae, vyhotovené v podobe stromu života. V tvaroch vetvových vidlicových krížov s vyobrazením telesných útrap Krista, s nepokojnou povrchovou modeláciou jeho tela, podla nej vidno na vetve viniča symbolicky visiaci strapec hrozna pred vylisovaním (Krista) (Spoločníková 2012, 11, 28).

Autorka velmi dobre poznala sakrálne pamiatky z Kolína nad Rýnom. Ako typické príklady daného štýlu uviedla tamojšie ukrižované telá, konkrétne z Kostola Panny Márie na Kapitole datovaného okolo roku 1305, korpusu z Kostola sv. Juraja zo 14. storočia a z Kostola sv. Severína. Tiež spomenula aj telo z kostola $\mathrm{v}$ Andernachu a datovala ho do obdobia rokov 1310 až 1320. Okrem rýnskych krí̌ov vyzdvihla taktiež podobné zo Slovenska, konkrétne zo Spiša. Zo všetkých jej najviac imponoval korpus ukrižovaného Krista z Matejoviec zhotovený okolo roku 1330. Plnšiu ikonografickú náplň mali však podla nej malované stromy života riešené technikou nástenných malieb, napr. na Slovensku v kostole v Žehre, lebo tie často prekonávali drevorezbársku teatrálnost’ (Spoločníková 2012, 11). Čiastočne korigovala starší názor spomínaného mad’arského umenovedca Dénesa Radocsaya (1967, 16n., obr. 6), že matejovský kríž pochádza z rokov 1330 až 1360 a bol samostatným dielom autora nezávisle od ostatných diel zo Sliezska a iných prác. Podla Spoločníkovej $(2012,32)$ gotická polychrómovaná plastika Krista z Matejoviec je vel'mi podobná plastike z farského kostola v Andernachu, ktorá mohla byt’ vzorom pre rezbu neznámeho majstra z Matejoviec. Plastika z Matejoviec je vysoká $120 \mathrm{~cm}$, korpus je tiež pripevnený na vetvový kríž.

Na záver uviedla, že matejovský kríž patrí k jedinečným príkladom zachovania pôvodného dreva flagelantského kríža (Spoločníková 2012, 28n.). Bolest’a trpitel'ský výraz sú ich charakteristickým znakom. Krvácajúce telo Krista podla nej obsahuje prvky dynamiky a expresivity. Mysticky odkrýva „bolestné vykúpenie hriešnikov tajomným a nepochopitelným spôsobom“ (Spoločníková 2012, 28). Zobrazenie nebeského tajomstva je podstatou náboženského umenia. Mária Spoločníková sa snažila vystihnút predovšetkým duchovné posolstvá sprostredkované sakrálnym umením prvej polovice 14. storočia. 


\section{Záverečné zhrnutie}

Procesie uhorských pútnikov do Cách ukončil ediktom v roku 1769 cisár Jozef II. Zakázal ich preto, lebo pochybných ludí, lupičov a tulákov ukrytých za pútnikov pribúdalo. Ludia sa mohli pohybovat' cudzinou bez obáv a často zneužívat pohostinnost̉ domácich. Na poslednej púti do Cách, ktorá sa uskutočnila $\mathrm{v}$ tom istom roku, bolo $\mathrm{v}$ Andernachu napočítaných 265 pútnikov (Luschin von Ebengreuth 1878, 89; Schäfer 2000, 63). V období „dlhého“ 19. storočia pokračovali dial'kové púte hlavne do Ríma, ktorý sa stal okrem náboženského strediska i diplomatickým centrom Európy (Ivanič 2019, 101-103).

Najstaršia správa o pomenovaní Ungarnkreuz pochádza z roku 1884 z pera Gerharda Terwelpa. Bola publikovaná v časopise Niederrheinischer Geschichtsfreund, v jeho 21. ročníku. Nezmienili sa o ňom v predošlých starších meritórnych prácach Friedrich Everhard von Mering, Christian Quix, Heinrich Joseph Floss, Arnold Luschin von Ebengreuth a ani nikto další. V archíve mesta Andernach sme ho spomenutý nenašli, ani početní nemeckí bádatelia, ktorí sa ním v minulosti zaoberali, nenašli dosial’ o ňom žiadnu zmienku.

V staršej literatúre sa opakuje fakt o pravidelnom uschovávaní (nejakého) kríža či krížov a viacerých zástav vo farskom mariánskom kostole v Andernachu. Autori považovali za velmi pravdepodobné, že dobre známy kríž pod menom uhorský skutočne pochádzal od uhorských pútnikov a zostal tu, pretože po zrušení ich putovania spomenutým cisárom sa sem už nevrátili (Terwelp 1884, 495). Nemal ho tak dalej kto pravidelne nosit do Kolína nad Rýnom. Moderná vedecká literatúra však uprednostňuje skeptický prístup k tomuto tvrdeniu (Godehard Hoffmann a iní). K dokázaniu toho, že kríž pochádzal od uhorských pútnikov, musíme byt̉ kritickí i my, pretože žiadne dôkazy zatial nepriniesol nikto. Gerhard Terwelp sa odvolal na ludovú tradíciu, tá by ale musela do roku 1884 pretrvat' viac ako sto rokov, teda celé štyri generácie. Bez povšimnutia nemôže zostat' ani fakt, že pri pútach v období baroka by uhorskí pútnici nenosili so sebou pravidelne každých sedem rokov do Cách alebo Kolína nad Rýnom viac ako štyristoročný gotický kríž s expresívne ukrižovaným Kristom. To je dost̉ málo pravdepodobné. A o tradícii vynášania tohto kríža ešte od obdobia stredoveku, od 14. storočia, nemôžeme ani uvažovat'.

Podobne skeptickí musíme byt i pri pátraní po pôvode kríža. Doposial sa k nemu vyjadrili viacerí autori, zväčša však iba preberali staršie názory a nové argumenty nepriniesli. Vyskytli sa ale medzi nimi i zaujímavé hypotézy. Fritz Witte v roku 1920 tvrdil, že cudzorodo vyznievali oba krucifixy, kolínsky z Kapitolu i andernachský, čo mu dovol’ovalo vyslovit, že „pri premýšlaní o ich pôvode sa treba orientovat na juh alebo slovansky ovplyvnené krajiny“. Teoreticky tak pripustil možnost' jeho uhorského pôvodu. Dénes Radocsay v roku 1967 naopak napísal, že známe kríže z Kolína nad Rýnom (St. Maria im Kapitol), Coesfeldu alebo z Andernachu od neznámych umelcov sa pri vykreslovaní smrtelných bolestí Krista vyznačovali „prehnaným expresionizmom“. Spišské kríže opačne „realistickou úprimnostou“. Kríž z Matejoviec a príbuzný kríž z Lendaku teda nemali podla neho priamy súvis s vidlicovými krížmi kolínskeho a sliezskeho okruhu. Godehard Hoffmann zašiel najdalej, v 2006 zistoval súvis medzi jednotlivými rezbárskymi dielami z celoeurópskeho hladiska. Andernachský krucifix označil ako velmi blízky $\mathrm{k}$ tomu na Kapitole v Kolíne nad Rýnom. Mal základné charakteristiky, ktoré ho s ním a jeho nástupníckymi prácami spájali - a preto ich všetky spolu oprávnene zoskupil do kolínskej skupiny. Našiel podobnosti i s krížom v Bocholte. Spišské kríže, žial', nepoznal. A aby sme to skomplikovali, Mária Spoločníková v roku 2012 tvrdila, že gotická polychrómovaná plastika Krista z Matejoviec bola vel'mi podobná plastike $\mathrm{z}$ farského kostola $\mathrm{v}$ Andernachu, ktorá mohla byt’ vzorom pre rezbu neznámeho majstra $\mathrm{z}$ Matejoviec. Teda štyria odborníci - štyri zaujímavé názory, ale otázka proveniencie tejto sakrálnej pamiatky zostáva nad’alej otvorená. 
Menšie nezhody ako pri pátraní po pôvode uhorského kríža z Andernachu panujú pri datovaní jeho vzniku. Najstaršia literatúra tento typ krížov širšie zarad’ovala do 14. storočia, presnejšie do prvej polovice 14. storočia (napr. Gerhard Terwelp), výnimočne na prelom 13. a 14. storočia (Fritz Witte). Voči tomuto konzervatívnemu prístupu nemožno ani dnes nič namietat. Novšie práce tieto názory iba spresňovali, resp. posunuli jeho vznik na začiatok 14. storočia (Klaus Schäfer). Mária Spoločníková ho pedantne zaradila do obdobia rokov 1310 až 1320. Jeho datovanie upravil Godehard Hoffmann - na základe porovnávania diel kolínskeho okruhu - a priklonil sa k druhej štvrtine 14. storočia (1325 - 1350). Argumentačne je Hoffmann najdôveryhodnejší, lebo vo výskume tohto typu pamiatok vychádzal z najpočetnejších analógií.

Na záver možno konštatovat, že výskum bolestných krížov vyrezaných v 14. storočí nie je ani zd’aleka ukončený a bude $\mathrm{v}$ ňom $\mathrm{v}$ budúcnosti potrebné pokračovat. Iba tak sa podarí na všetky nastolené otázky všeobecne, i v súvislosti s krížom v Andernachu, odpovedat. Fenomén Crucifixus dolorosus si ako neoddelitel’ná súčast' kultúrnej identity Európy našu pozornost’ určite zaslúži.

\section{REFERENCES}

\section{Primary sources}

Landeshauptarchiv Koblenz, Bestand 612: Andernach - Urkunden, Nr. 483, 484 /Arbeitsfilm 16767 (dalej LHAK, B.612, 483, 484)

Landeshauptarchiv Koblenz, Bestand 612: Andernach - Akten, Hospitalrechnungen, Arbeitsfilm 14789 (dalej LHAK, B.612, 14789)

Landeshauptarchiv Koblenz, Bestand 612: Andernach - Akten, Almosenrechnungen, Arbeitsfilm 14791, 14792 (d’alej LHAK, B.612, 14791, 14792)

\section{Secondary sources}

750 Jahre Stiftung. 2000. 750 Jahre Stiftung St.-Nikolaus-Stiftshospital in Andernach. Andernach. Adams, Peter. 1955. Kurzgefaßte Geschichte der Stadt Andernach. Andernach.

Bakó, Ferenc. 1989 - 1990. Andornak. Adatok az Egri-völgy betelepülésének történetéhez. In Agria. Az Egri Múzeum Évkönyve - Annales Musei Agriensis 25-26, 494-495.

Beissel, Stephan. 1902. Die Aachenfahrt. Verehrung der Aachener Heiligthümer seit den Tagen Karls des Großen bis in unsere Zeit. Ergänzungsheft zu den Stimmen aus Maria Laach 82. Freiburg im Breisgau.

Blaeser, Franz - Press, Dieter - Schäfer, Heinz - Scholz, Wolfgang. 2011. Unterwegs auf dem Eifel-Camino : Der Wanderführer für den Jakobsweg von Andernach-Namedy nach Trier. Norderstedt.

Divald, Kornél. 1906. Szepesvármegye müvészeti emlékei II. Lőcse.

Ernstberger, Birgit. 2002. Der gotische Crucifixus dolorosus aus der Liebfrauenkirche in Andernach / Rhein. Eine Untersuchung hinsichtlich Technologie und Erhaltungszustand sowie Erstellung eines Konservierungskonzeptes. Diplomarbeit FH-Köln Januar 2002. Abstract http://doczz. net/doc/6151654/abstracts-der-diplomarbeiten.

Fischer, Wolfgang P. 2008. Das älteste Andernacher Schützenbuch von 1426 bis 1656. Ein Beitrag zum 650jährigen Jubiläum Schützenbruderschaft. Andernach.

Floss, Heinrich Joseph. 1855. Geschichtliche Nachrichten über die Aachener Heiligthümer. Bonn. 
Glatz, Joachim (ed.). 1984. Katholische Pfarrkirche Mariä Himmelfahrt in Andernach am Rhein (Liebfrauenkirche). München.

Heizmann, Berthold. 1981. Wallfahrtsorte im Rheinland. In Wallfahrt im Rheinland. Köln, 113-162.

Heyen, Franz-Josef (ed.). 1988. Andernach : Geschichte einer rheinischen Stadt. Andernach.

Heyen, Franz-Josef. 1979. Inventar des Archivs der Stadt Andernach. Bd. 6 Urkunden des Klosters Namedy. Koblenz.

Hoffmann, Godehard. 2006. Das Gabelkreuz in St. Maria im Kapitol zu Köln und das Phänomen der Crucifixi dolorosi in Europa. Worms (Arbeitsheft der rheinischen Denkmalpflege, Bd. 69). Ivanič, Peter. 2019. Encyklika Grande munus a jej odozva u slovenských katolíkov [The Encyclical Grande Munus and a Response to It From the Slovak Catholics]. Konštantínove listy [Constantine's Letters] 12/2, 98-106.

Kampis, Antal. 1923. A középkori magyar faszobrászat történetének vázlata 1450-ig. Budapest. Keyser, Erich (ed.). 1964. Städtebuch Rheinland-Pfalz und Saarland. Stuttgart.

Luschin von Ebengreuth, Arnold. 1878. Die windische Wahlfahrt an den Niederrhein. In Pick, Richard (ed.). Monatsschrift für die Geschichte Westdeutschlands. 4. Jahrgang. Trier, 436-466, 259.

Luschin von Ebengreuth, Arnold. 1887. Windische Wallfahrer am Niederrhein. In Archiv für Heimatskunde von Franz Schumi. Geschichtsforschungen, Quellen, Urkunden und Regesten. 2. Band. Laibach, 72-108.

Mering, Friedrich Everhard - Reischert, Ludwig. 1838. Zur Geschichte der Stadt Köln am Rhein : Von ihrer Gründung bis zur Gegenwart. Zweiter Band. Köln.

Meyer, Anne-Rose. 2011. Homo Dolorosus. Körper-Schmerz-Ästhetik. München.

Nemeš, Jaroslav. 2019. Príspevok k založeniu uhorskej kaplnky v Aachene králom Ludovítom I. (1360). In Historický časopis : vedecký časopis o dejinách Slovenska a strednej Európy 67/1, $3-22$.

Neukirchen, Anton. 2004. Die Aachen-Frankfurter Heerstraße als Pilgerstraße : die Betreuung der Ungarnpilger am Frauenpütz in Eckendorf. In Heimatjahrbuch Kreis Ahrweiler 61, 126-129.

Pauly, Michel - Uhrmacher, Martin. 2006. Die Koblenzer Hospitäler in zentralörtlicher Perspektive.

In Ed. Irsigler, Franz. Zwischen Maas und Rhein. Beziehungen, Begegnungen und Konflikte in einem europäischen Kernraum von der Spätantike bis zum 19. Jahrhundert. Trier, 331-347.

Pauly, Michel. 2007. Peregrinorum, pauperum ac aliorum transeuntium receptaculum : Hospitäler zwischen Maas und Rhein im Mittelalter. Stuttgart.

Quix, Christian. 1838. Beiträge zur Geschichte der Stadt und des Reiches Aachen und ihrer Umgebungen. Zweites Bändchen. Aachen.

Radocsay, Dénes. 1967. A középkori Magyarország faszobrai. Budapest.

Rosch, Adolf. 1955. 700 Jahre Caritas. Stiftshospital zum Hl. Nikolaus in Andernach am Rhein. (s.d.).

Schäfer, Klaus. 1998. Andernach am Rhein. Die Reihe Archivbilder. Erfurt.

Schäfer, Klaus. 2000. Anmerkungen zur Geschichte des Andernacher Hospitals im Mittelalter und der frühen Neuzeit. In 750 Jahre Stiftung St.-Nikolaus-Stiftshospital in Andernach. Andernach, 57-94.

Schneider, Alfréd. 2012. Ungarn-Kreuz, vagy Ungarnkreuz? 1. Rész. In A Magyar-Hon-Lap. http:// mkdsz.hu/content/view/27288/210/.

Schwartzenberg, Heinrich von. 2000. Die Aachen-Frankfurter Heerstraße. In Im Göhltal. Zeitschrift der Vereinigung für Kultur, Heimatkunde und Geschichte im Göhltal 67. August, 9-24.

Spoločníková, Mária. 2012. Corpus Christi. Poklady gotiky v sochárskom umení východného Slovenska. Trnava. 
Stabéj, Jože. 1967. Die alten Wallfahrten der Slovenen an den Rhein. In Zeitschrift des Aachener Geschichtsvereins 78, 97-160.

Terwelp, Gerhard. 1884. Das Ungarkreuz in der Pfarrkirche zu Andernach. In Niederrheinischer Geschichtsfreund 21/6, 166-167.

Thoemmes, Elisabeth. 1937. Die Wallfahrt der Ungarn an den Rhein. Aachen.

Trier, Eduard. 1954. Die Freilegung des „Ungarnkreuzes“ von Andernach. In Kunstchronik : Monatsschrift für Kunstwissenschaft, Museumswesen und Denkmalpflege 7, Zeitschriftenheft April, 93-95, 99.

Wagner, Vladimír. 1948. Vývin výtvarného umenia na Slovensku. Bratislava (odtlačok Slovenskej vlastivedy, diel V., sv. 2.).

Weinand, Helmut. 2012. Illustrierter Domführer durch die katholische Kirche „Maria Himmelfahrt“ in Andernach. 3. Auflage. Koblenz.

Witte, Fritz. 1921. Mittelalterliche Kruzifixe. In Zeitschrift für christliche Kunst 34/1-3, 21-25.

Witte, Fritz. 1920. Mystik und Kreuzesbild um 1300. In Zeitschrift für christliche Kunst 33/9-10, 117-124.

Wynands, Dieter P. J. 1986. Geschichte der Wallfahrten im Bistum Aachen. Aachen.

SUMMARY: ON THE JOURNEY TO AACHEN. HUNGARIAN PILGRIM CROSS IN ANDERNACH. Processions of Hungarian pilgrims to Aachen were concluded by the edict of the Emperor Joseph II in 1769. He prohibited them due to an increasing number of devious people, robbers and rogues disguised as pilgrims. People could cross borders of foreign countries and they very often took advantage of the hospitality of natives. During the last pilgrimage to Aachen, which took place in the same year, 265 pilgrims were recorded in Andernach.

The oldest report on the name "Ungarnkreuz" dates back to 1884 and was made by Gerhard Terwelp. It was published in the journal Niederrheinischer Geschichtsfreund in its $21^{\text {st }}$ volume. Friedrich Everhard von Mering, Christian Quix, Heinrich Joseph Floss, Arnold Luschin von Ebengreuth and nobody else had mentioned it in preceding older meritorious works. It was not recorded in the archives of the town Andernach, and even numerous German researchers that dealt with it in the past have not found any reference so far.

In older literature there repeats a fact about regular storage of a cross or crosses and several flags in the parish church of the Blessed Virgin Mary in Andernach. Authors considered as probable that the well-known cross with the name "Hungarian" really belonged to Hungarian pilgrims and it remained here, as pilgrims did not return here after the cancellation of pilgrimages by the Emperor. The means there was nobody who could carry it regularly to Cologne. However, modern scientific literature prefers a sceptical approach towards the statement (Godehard Hoffman and other). Even we must be critical to prove that the cross originates from Hungarian pilgrims as there is no evidence yet. Gerhard Terwelp refers to folk traditions. It means that the tradition existed until 1884, and thus it endured for more than a hundred years, i.e., four full generations. We cannot even avoid the fact that Hungarian pilgrims would not carry every seven years to Aachen or Cologne the 400-year old gothic cross with the expressively crucified Christ. That is less likely. Moreover, we cannot speak of the tradition of carrying this cross from the period of the Middle Ages from the 14th century.

We also have to be sceptical in our search for the origin of the cross. So far several authors have commented on it, but they predominantly reproduced older opinions and they have not provided new arguments. However, interesting hypotheses have originated among them. Fritz Witte in 1920 argued that both crosses, the one for Cologne (St. Maria im Kapitol) and the one from Andernach, looked outlandish and that allowed him to state that "when thinking about their origin, we should be concentrated on the South or countries affected by Slavs". He theoretically admitted a possibility of its Hungarian origin. On the contrary, Dénes 
Radocsay in 1967 wrote that the well-known crosses from Cologne (St. Maria im Kapitol), Coesfeld or Andernach by unknown artists had features of "excessive expressionism" in the depiction of mortal pains of Christ. Crosses from Spis, on the contrary, had features of "realistic sincerity". In his opinion, the cross from Matejovce and the related cross from Lendak did not have a direct connection with the forked crosses from Cologne and Silesian areas. Godehard Hoffmann went farthest when in 2006 investigated a connection between individual carving works from the European perspective. The cross from Andernach was designated as very related to the one in Cologne. It contained basic features that connected it with it and all successive works, and therefore he was correct to bring them together in the Cologne group. He also traced similar features with the cross in Bocholt. Unfortunately, he did not know crosses from Spis region. So, to make it "more complicated", Mária Spoločníková in 2012 argued that the gothic polychrome sculpture of Christ in Matejovce was very similar to the sculpture from the parish church in Andernach and it could be a model for the unknown author from Matejovce. To conclude, four researchers and professionals and four interesting opinions. But the question of the provenance of the sacral relic still remains open.

In dating of its creation there exist smaller differences than in the search for the origin of the Hungarian cross from Andernach. The oldest literature classifies this type of crosses in the 14th century, more precisely in the first half of the 14th century (e.g., Gerhard Terwelp), exceptionally in the turn of the 13th and 14th centuries (Fritz Witte). We cannot object to this conservative approach even today. Newer works only specified, resp. moved it to the beginning of the 14th century (Klaus Schäfer). Mária Spoločníková precisely set its creation in the period from 1310 to 1320. Its dating was revised by Godehard Hoffman, based on the comparison of works from the Cologne area, and he favoured the second quarter of the 14th century $(1325-1350)$. Following the facts, Hoffmann is the most reliable as his results follow the highest number of analogies.

As a conclusion, we may assume that research of the crosses carved in the 14th centuries has not been completed by far and it is necessary to proceed. Only under this condition, we may answer all raised questions in general and also in relation to the cross in Andernach. The phenomenon of Crucifixus dolorus deserves our attention as a solid part of the cultural identity of Europe.

doc. Mgr. Jaroslav Nemeš, PhD.

Department of Mediamatics and Cultural Heritage

Faculty of Humanities

University of Žilina

Univerzitná 8215/1

01026 Žilina

Slovakia

jaroslav.nemes@fhv.uniza.sk 


\section{Prílohy / Appendix}

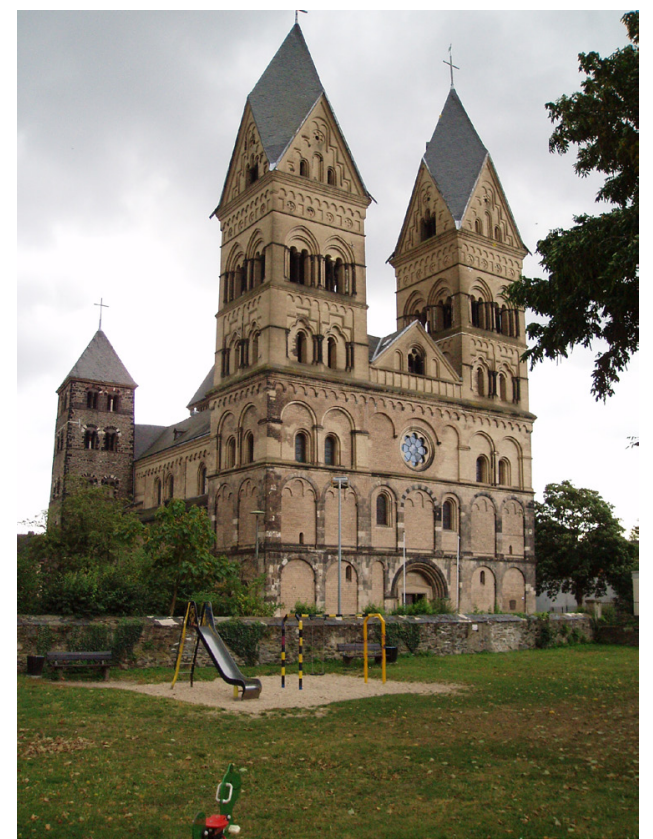

Obr. 1 Kostol Panny Márie v Andernachu. Foto autor

Figure 1 Blessed Virgin Mary Church in Andernach. Photo: author

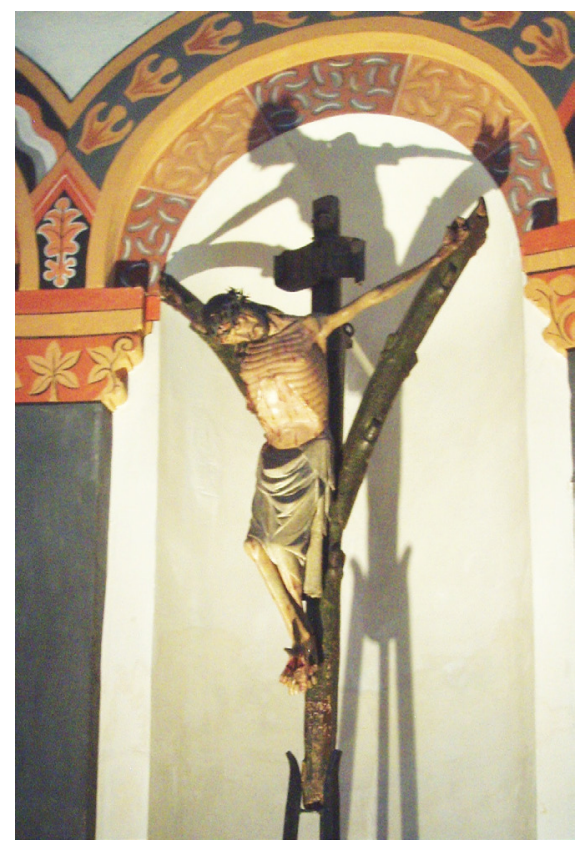

Obr. 2 Vidlicový kríž z Andernachu. Foto autor

Figure 2 The Y-shaped Cross from Andernach. Photo: author 


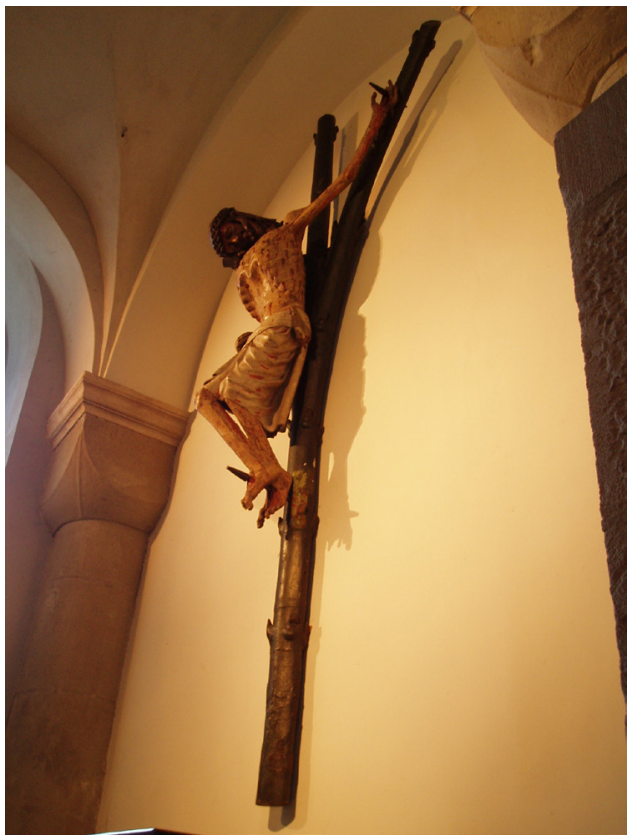

Obr. 3 Vidlicový kríž z kolínskeho Kapitolu. Foto autor Figure 3 The Forked Cross in Capitol in Cologne. Photo: author 